\title{
Property Ownership and Monitoring for the Modification of Martin and Bowie Streets, San Antonio, Bexar County, Texas
}

I. Waynne Cox

Follow this and additional works at: https://scholarworks.sfasu.edu/ita

Part of the American Material Culture Commons, Archaeological Anthropology Commons, Environmental Studies Commons, Other American Studies Commons, Other Arts and Humanities Commons, Other History of Art, Architecture, and Archaeology Commons, and the United States History Commons

Tell us how this article helped you.

This Article is brought to you for free and open access by the Center for Regional Heritage Research at SFA ScholarWorks. It has been accepted for inclusion in Index of Texas Archaeology: Open Access Gray Literature from the Lone Star State by an authorized editor of SFA ScholarWorks. For more information, please contact cdsscholarworks@sfasu.edu. 
Property Ownership and Monitoring for the Modification of Martin and Bowie Streets, San Antonio, Bexar County, Texas

\section{Creative Commons License}

\section{(c) (1) \&}

This work is licensed under a Creative Commons Attribution-NonCommercial 4.0 International License 


\section{DIRODERTY OWNERSMID AND MONITORNAG}

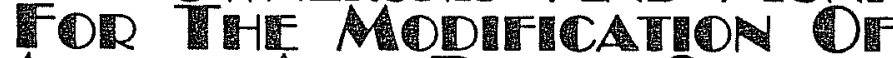
MARTIN AND BOWIE STIRTEIS. SAN ANIONIO, BEXAR COUNIY, TEXI

\section{Wayme Cox}

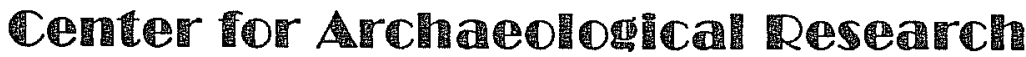

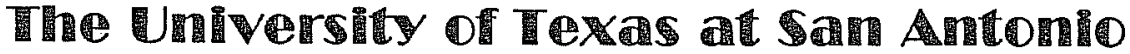
Archacological Survey Remort, ND. 185 



PROPERTY OWNERSHIP AND MONITORING FOR THE MODIFICATION OF MARTIN AND BOWIE STREETS, SAN ANTONIO, BEXAR COUNTY, TEXAS

I. Waynne Cox

Center for Archaeological Research The University of Texas at San Antonio ${ }^{8}$ Archaeological Survey Report, No. 185 
The following information is provided in accordance with the General Rules of Practice and Procedure, Chapter 41.11 (Investigative Reports), Texas Antiquities Committee:

1. Type of investigation: archaeological monitoring and testing;

2. Project name: Martin-Bowie (East);

3. County: Bexar;

4. Principal investigator: Jack D. Eaton;

5. Name and location of sponsoring agency: Day \& Zimmermann, Inc., San Antonio, Texas;

6. Texas Antiquities Committee Permit No. 606;

7. Published by the Center for Archaeological Research, The University of Texas at San Antonio, San Antonio, Texas 78285-0658, 1990.

This book is printed on acid-free paper (Cougar No. 1 Opaque Offset).

A list of publications offered by the Center for Archaeological Research can be obtained by sending $\$ 1.00$ to the Center for Archaeological Research, The University of Texas at San Antonio, San Antonio, Texas 78285-0658. 


\begin{abstract}
In February 1987, the Center for Archaeological Research at The University of Texas at San Antonio conducted archival research to determine the historic significance of structures in New City Block 552 in downtown San Antonio. One structure, the Gallagher building, proved worthy of preservation. The Center then monitored the demolition of the other standing structures in the area of Martin and Bowie Streets. Limited backhoe trenching was conducted to locate the Acequia Madre, which proved to be outside the property limits. Later, monitoring to the north revealed its location farther to the west.
\end{abstract}


TABLE OF CONTENTS

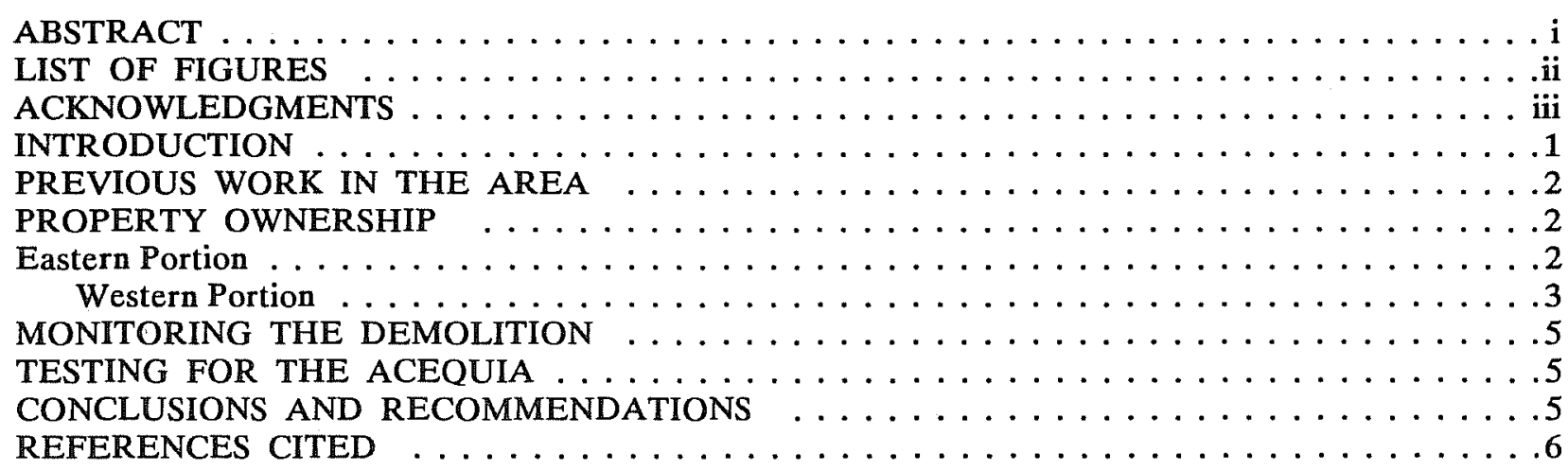

\section{LIST OF FIGURES}

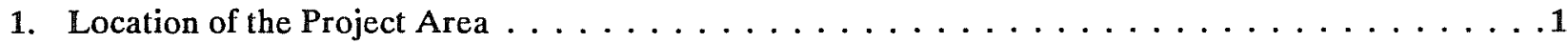

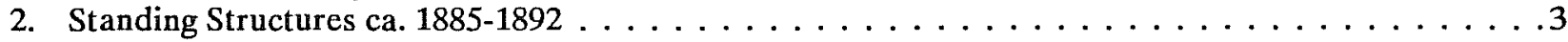

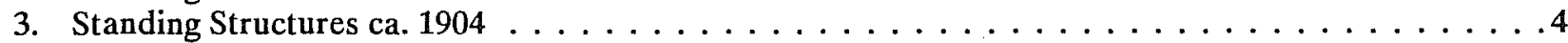

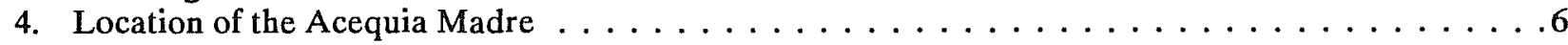




\section{ACKNOWLEDGMENTS}

We wish to thank J. Michael Carter and Paul Foster of Day \& Zimmermann, Inc., for their assistance throughout the project. Our thanks also to Bradley Boegner, Boegner and Associates, for his cooperation during the demolition and testing phases. Arthur Wendt, Stinson Field, also rendered invaluable assistance in relocation of the stone salvaged during the project. Special thanks to Frances Meskill for drafting the illustrations for this report. 



\section{INTRODUCTION}

In February 1987, the Center for Archaeological Research (CAR), The University of Texas at San Antonio (UTSA), entered into a contract with Day \& Zimmermann, Inc., to conduct archival research of New City Block (NCB) 552 in downtown San Antonio (Fig. 1). The purpose was to determine if any of the structures to be impacted by the modification of the connection of Martin and Bowie Streets had historical significance. Research revealed that one structure merited protection, the Gallagher building, constructed in ca. 1879. The CAR was further contracted to monitor the demolition of structures at 727 and 737 East Houston Street and to conduct limited testing to determine if the Acequia Madre (41 BX 8), irrigation ditch for Mission San Antonio de Valero (the Alamo), was within the property acquired by the City of San Antonio.

Archival research was completed in April 1987, and a preliminary report was submitted to Day \& Zimmermann, Inc., at that time. Demolition of the structures occurred in October of that year. Testing for the acequia was conducted in February 1988. Texas Antiquities Committee Permit No. 606 was issued for this project. Jack D. Eaton, acting director of the CAR, served as principal investigator. All notes, photographs, and other pertinent documents related to this project are curated at the CAR laboratory.
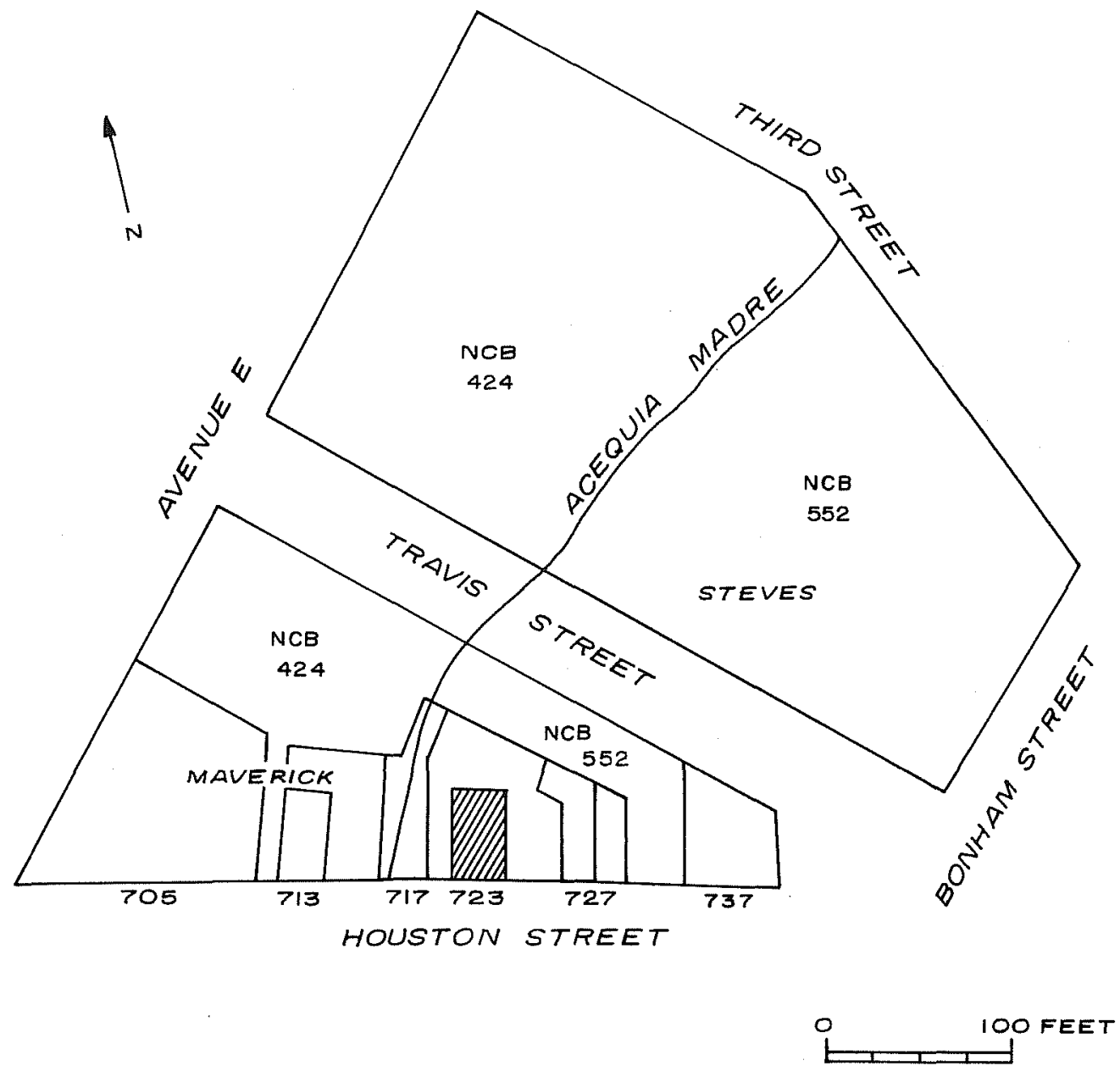

Figure 1. Location of the Project Area. Hatched area indicates the Gallagher building. Adapted from 1952 insurance map (Sanborn Map and Publishing Company, Ltd. 1952). 


\section{PREVIOUS WORK IN THE AREA}

The previous archaeology of the area has been primarily concentrated on the grounds of the Alamo, directly to the south of this project. Reports by Schuetz (1966, 1973), Tunnell (1966), Greer (1967), Sorrow (1972), Adams and Hester (1973), Fox, Bass, and Hester (1976), and Eaton (1980) have dealt with the investigations at Mission San Antonio de Valero. Investigations of the Acequia Madre have been reported by Schuetz (1970), Cox (1985), and Fox (1985).

\section{PROPERTY OWNERSHIP}

The study area, the southeastern portion of NCB 552 , was originally a part of the lands granted to Mission San Antonio de Valero by the Spanish Crown (Habig 1968:42). Upon secularization in 1793, much of the mission land that served as the fields for the production of crops to support the neophytes was distributed to the Indians and various petitioners. Those lands not so distributed reverted to the Spanish government. The plot outside the northeast corner of the mission compound, from the acequia to Nacogdoches Street (now Bonham Street) was granted in January 1818 to Diego Perez, a soldier of the Flying Company of San Carlos de Paras (Spanish Records Document No. 37). A portion of this area was assigned in the 1836 Alamo battle by General Antonio Lopez de Santa Anna to the Second Battalion of Tolucas and three companies from San Luis under Colonel Francisco Duque (Peña 1975:45). This area was also the sector into which Colonel Manuel Romero and his two companies from the Matamoros and Jimenez Battalions were driven after his eastern attack was diverted by the cannon of the defenders (Lord 1961:158).

\section{EASTERN PORTION (Steves Lot)}

By 1831, the eastern portion of the Perez grant had been acquired by Juan Moga, who sold it to Jose Francisco Martinez. Martinez sold the property to Jesus Cantu in 1840 ( $D R$ Vol. A2:319). In September 1858 , the parcel was conveyed by Vicente and Juan Cantu to Edward Elmendorf ( $D R$ Vol. R1:69). Elmendorf died in 1865, and his wife and sole heir Emilie, sold it to H. Moye and Edward Degener in April of the following year (Chabot 1937:404; DR Vol. U1:15). Moye sold his interest to Degener in January 1868, and Degener conveyed his interest to Eduard (Edward) Steves in 1869 (DR
Vol. U2:434, 472). Edward Steves, a native of Barmen, Elberfeld, Germany, established one of the first lumberyards in San Antonio in 1866. The yard was first located at Blum and Bowie Streets, but soon relocated to Alamo Plaza. The lumberyard was never located on this property, and it is likely that he used it for surplus storage.

There is no indication in any of these transfers of any substantial improvements to the property. However in 1873, there was a one-story structure, with detached building to the rear, facing Houston Street approximately midway between the acequia and Nacogdoches Street (Koch 1873). By 1885, this structure no longer existed, and a one-story structure with frame appendages had been constructed on the western portion of the property (631 Houston Street, later 731 Houston Street; Fig. 2). At that time, the rear of the lot was covered by a complex of frame structures for the San Antonio Transfer Company. The corner of Houston and Nacogdoches Streets was occupied by an iron-clad blacksmith shop operated by Fredrick Krog and Adam Franz (Sanborn Map and Publishing Company, Ltd. 1885; Steinfeldt 1979:103).

In 1887, Edward Steves and Edward Gallagher exchanged a small strip of land on the western edge of the property ( $D R$ Vol. 57:8). By 1888, a small brick office had replaced the stone structure at 631 Houston Street (later numbered 731; Sanborn Map and Publishing Company, Ltd. 1888). In March 1890 , Steves sold the property to Thomas and Charles Mullaly for $\$ 24,000$ ( $D R$ Vol. 65:428). In October of the same year, Thomas and Charles Mullaly conveyed the plot to George W. and Daniel T. Skinner, both residents of Colorado, for $\$ 40,000$ (DR Vol. 65:489). Their intent was apparently to lease the property, for in 1892 it was still occupied by the San Antonio Transfer Company, and in $\mathbf{1 8 9 6}$ by Carter and Mullaly Transfer Company in the same buildings as shown in previous insurance maps (Sanborn Map and Publishing Company, Ltd. 1885, 1892, 1896).

In 1895, George Skinner transferred his half interest to Daniel Skinner, and in 1899 , his widow, Mary L., sold the property to John T. Skinner of Onondaga, New York (DR Vol. 140:275, Vol. 185:228). In 1903, John Skinner sold the property, in three parcels, to George Findlay, David Logan, and T. P. Walsh (DR Vol. 212:528, Vol. 250:233). George, Ivie, and James Findlay moved their Findlay Manufacturing Company from Casino Street at that time and constructed the stone building at 735 East Houston Street, which angled at the back to connect with the frame complex at the rear of the lot (City Directory 1903-1904; Sanborn Map and Publishing Company, Ltd. 1904; Fig. 3). By 


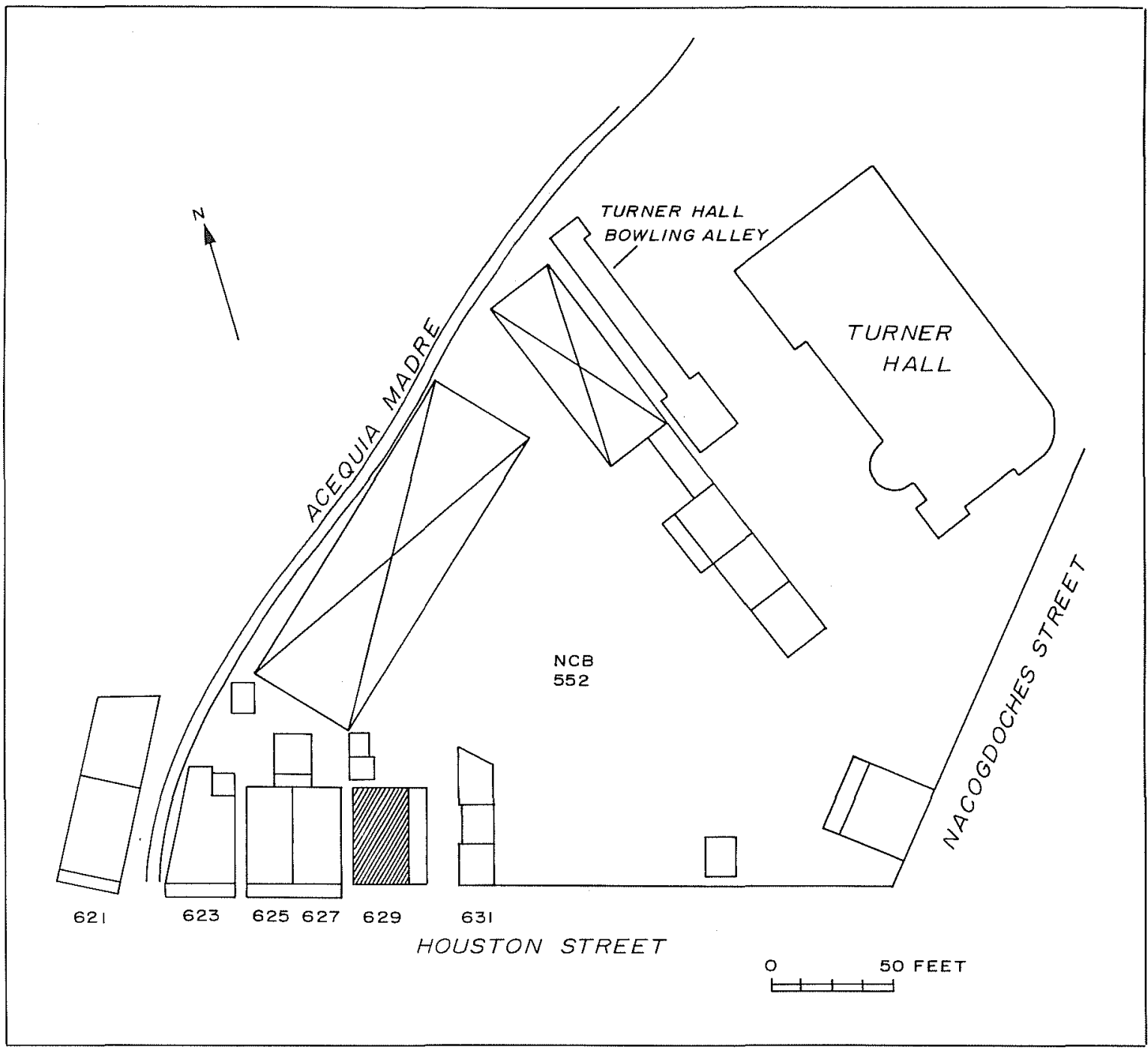

Figure 2. Standing Structures ca. 1885-1892. Hatched area indicates the Gallagher building. Adapted from 1892 insurance map (Sanborn Map and Publishing Company, Ltd. 1892). Note: Nacogdoches Street is now Bonham Street.

1910, the building was vacant, and in 1914 was occupied by the E.J. Jackson Automobile Company (City Directories 1903-1914, Sanborn Map and Publishing Company, Ltd. 1912). In approximately 1940, the extension of Travis Street eliminated the rear portion of the lot and the Walsh property (City Directories 1939-1942; Sanborn Map and Publishing Company, Ltd. 1950).

\section{WESTERN PORTION (Gallagher Lot)}

In June 1840, Peter Gallagher purchased the property "in a northeast direction from the Alamo Church measuring 50 varas (138.85 feet) . . . bounded on the west by the ditch that runs near the said Church" from Luciano Navarro (DR Voll. A2:319). Luciano Navarro had inherited the land from his brother, Eugenio, who had purchased it from Pedro del Toro in 1837, whose wife had inherited it from her mother, Juana Travieso ( $D R$ Vol. B1:228). Peter Gallagher died October 30, 1878 , and this portion of his estate, with other 


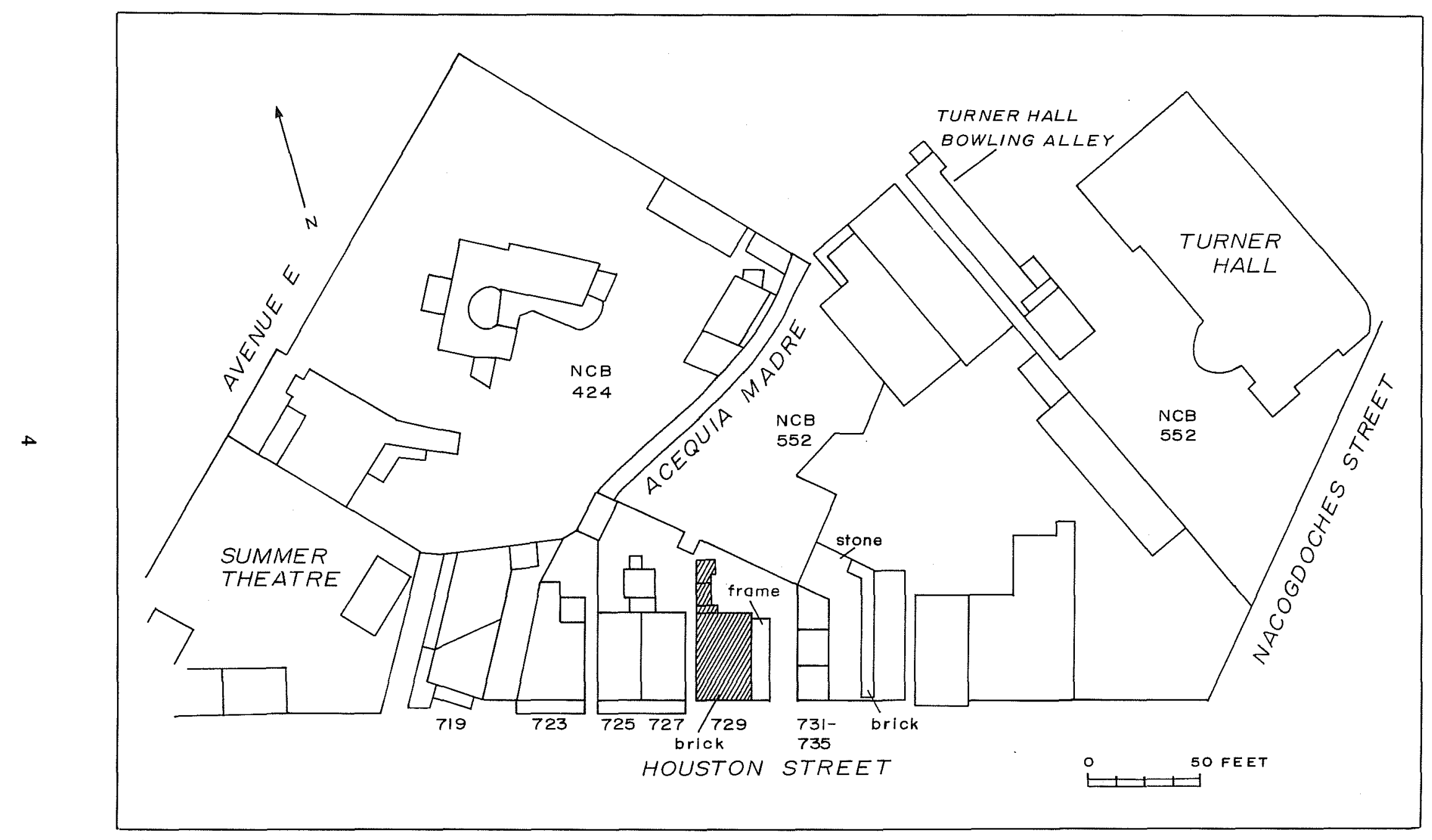

Figure 3. Standing Structures ca. 1904. Hatched area indicates the Gallagher building. Adapted from 1904 insurance map (Sanborn Map and Publishing Company, Ltd. 1904). Note: Nacogdoches Street is now Bonham Street. 
properties, was awarded to his brother, Edward J. Gallagher (Webb 1952:661; DR Vol. 15:230). In 1879-1880, Edward Gallagher relocated his business and residence to the newly acquired property and constructed the two-story brick building at 725-727 East Houston Street (City Directories 1877-1880). The building appears on an 1885 insurance map at 625-627 East Houston Street (Sanborn Map and Publishing Company, Ltd. 1885). In 1887, the property adjustment to the rear of the lot, previously mentioned, was transacted ( $D R$ Vol. 57:8). By 1892, the second-story wooden porch, still present, is indicated on an insurance map (Sanborn Map and Publishing Company, Ltd. 1892). In 1895, Gallagher relocated his business and residence to Cherry Street, and the Houston Street address became rental property (City Directories 1895-1938).

\section{MONITORING THE DEMOLITION}

Demolition of the structures at 727 and 737 East Houston Street, began October 10, 1987. The Gallagher building, as previously discussed, was selected for preservation and anticipated renovation. A $977 \mathrm{~L}$ front-end loader was utilized to dismantle the structures beginning with the stone structure on the back of the Findlay building. As demolition progressed, it was discovered that the Findlay building (727 East Houston Street) contained almost twice as much cut limestone than had been anticipated. Demolition was halted to notify the City Historic Preservation Office. After further discussion and evaluation, permission was granted to proceed. All cut limestone blocks were salvaged and transported to a city storage location for future use. Demolition was concluded October 23, 1987.

\section{TESTING FOR THE ACEQUIA}

After the debris around the Gallagher building was cleared, the archaeological team returned February 1, 1988, and began trenching with a backhoe in an attempt to locate the acequia. The first trench was opened across the middle of the Gallagher lot, approximately three feet east of the property line acquired by the city. When that trench revealed no evidence of the acequia, a second trench was opened to the north and nearer the property line. When this trench failed to locate the acequia, a third trench was opened farther north all the way to the extent of the city's property, again with negative results. The few artifacts encountered were of recent date and not collected. It became obvious at this point that the acequia was not within the city's acquired property boundaries. Further construction to the north of Travis Street later exposed the stone-lined acequia and confirmed the fact that its path carried it just to the west of the city's property (Fig. 4).

\section{CONCLUSIONS AND RECOMMENDATIONS}

The two-story brick building located at 725-727 (now 723) East Houston Street was constructed ca. 1879-1880 by Edward Gallagher for his construction firm and also served as his residence. He later constructed an additional building directly to the east to serve as his office (ca. 1889-1890), which was replaced or greatly modified by a fireproof structure after 1922.

The stone structure at 731-735 East Houston Street (later 737) was constructed ca. 1903 by the Findlay brothers. The front of this building was modified by a brick facade after 1922 . However, the obliquely oriented stone structure to the rear was also constructed in 1903 along with the other building. The odd orientation of this portion was dictated by its original intent, to link the building facing Houston Street to the already existing frame structure on the rear of the property that was to become the manufacturing complex for the business. The stone is unusual for the period, but not entirely unique. Similarly quarried stone can be found incorporated into the chapel of the Alamo, a result of modification to the building effected by $\mathrm{H}$. Grenet in 1876. The material is also similar to the stone utilized in the construction of the Alamo Museum built in 1936. The mortar used in the structure is cement with a heavy fly-ash composition. Fly-ash was not utilized in construction until after 1900 (Andrew Perez, personal communication).

The remaining structure, the Gallagher building ( 723 Houston Street), has been recognized as historically significant by the City Historic Preservation Office and is scheduled for restoration and reuse by the city (Patricia Osborne, personal communication). Although the Acequia Madre does not lie within the city property, it is probably eligible for nomination to the National Register of Historic Places and to be designated as a State Archeological Landmark. Therefore, if further work is anticipated in the area of the acequia, archaeological monitoring and investigations should be performed. 


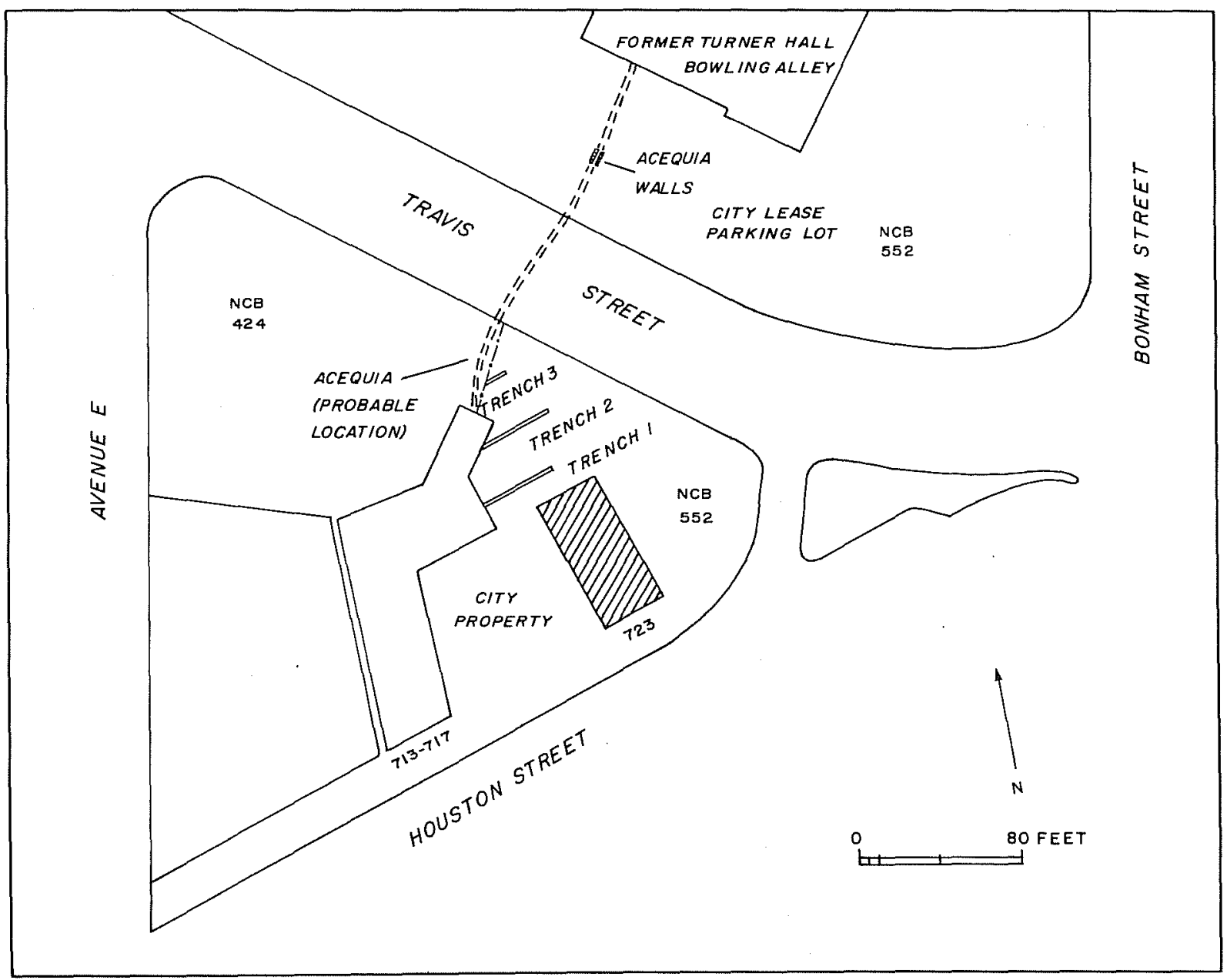

Figure 4. Location of the Acequia Madre. Indicated are the test trenches. The hatched area is the Gallagher building.

\section{REFERENCES CITED}

Adams, R. E. W. and T. R. Hester

1973 Letter to Dr. Fred Wendorf, Chairman, Texas Antiquities Committee, concerning completion of excavations at Mission San Antonio de Valero, November 26.

Bexar County, Texas

Deed Records (DR)

Originals and microfilm located in the County Clerk's Office, Bexar County Courthouse, San Antonio, Texas.

\section{Spanish Records}

Located in the Bexar County Archives, County Clerk's Office, Bexar County Courthouse, San Antonio, Texas.
Chabot, $\mathbf{F}$.

1937 With the Makers of San Antonio. Artes Graficas, San Antonio, Texas.

\section{City Directories}

1877- Located at the Daughters of the Republic 1942 of Texas Research Library, San Antonio.

\section{Cox, I. W.}

1985 10th Street Substation Excavation of the Acequia Madre (41 BX 8), San Antonio, Bexar County, Texas. Center for Archaeological Research, The University of Texas at San Antonio, Archaeological Survey Report 153. 
Eaton, J. D.

1980 Excavations at the Alamo Shrine (Mission San Antonio de Valero). Center for Archaeological Research, The University of Texas at San Antonio, Special Report 10.

Fox, A. A.

1985 Testing for the Location of the Alamo Acequia (41 BX 8) at HemisFair Plaza, San Antonio, Texas. Center for Archaeological Research, The University of Texas at San Antonio, Archaeological Survey Report 142.

Fox, A. A., F. A. Bass, Jr., and T. R. Hester

1976 The Archaeology and History of Alamo Plaza. Center for Archaeological Research, The University of Texas at San Antonio, Archaeological Survey Report 16.

Greer, J. W.

1967 A Description of the Stratigraphy, Features and Artifacts from an Archeological Excavation at the Alamo. State Building Commission Archeological Program, Report 3, Austin.

Habig, M.

1968 The Alamo Chain of Missions, San Antonio's Five Old Missions. Franciscan Herald Press, Chicago.

Koch, A.

1873 Bird's Eye View of the City of San Antonio, Bexar County, Texas, 1873. Copy of map at the Center for Archaeological Research, The University of Texas at San Antonio. From the collection of the San Antonio Museum Association. Published by R. H. Holland.

Lord, W.

1961 A Time To Stand. University of Nebraska Press, Lincoln, Nebraska.

Peña, J. E. de la

1975 With Santa Anna in Texas. Translated and edited by Carmen Perry. Texas A\&M University Press, College Station.
Sanborn Map and Publishing Company, Ltd.

1885- Insurance maps of San Antonio located in

1952 the John Peace Library, The University of Texas at San Antonio.

Schuetz, M.

1966 Historical Background of the Mission San Antonio de Valero. State Building Commission Archeological Program, Report 1, Austin.

1970 Excavation of a Section of the Acequia Madre in Bexar County, Texas and Archeological Investigations at Mission San Jose in April 1968. Texas Historical Survey Commission, Archeological Report 19, Austin.

1973 Archeological Investigations at Mission San Antonio de Valero, the Second Patio. Unpublished manuscript, Office of the State Archeologist, Austin.

Sorrow, W. M.

1972 Archeological Salvage Excavations at the Alamo (Mission San Antonio de Valero). Texas Archeological Salvage Project, The University of Texas at Austin, Research Report 4, Austin.

Steinfeldt, C.

1979 San Antonio Was: Seen Through A Magic Lantern. San Antonio Museum Association, San Antonio.

Tunnell, C.

1966 A Description of Enameled Earthenware from an Archeological Excavation at Mission San Antonio de Valero (The Alamo). State Building Commission Archeological Program, Report 2, Austin.

Webb, W. P. (editor-in-chief)

1952 The Handbook of Texas. Volume I. The Texas State Historical Association, Austin. 



